\title{
The Role of Microfinance in the Development of Small and Medium Enterprises (SMEs)
}

\author{
Asad Khan \\ Student, City University of Science and Information Technology \\ Dalazak Road Peshawar, Pakistan \\ Daniyal Inayat \\ Student, City University of Science and Information Technology \\ Dalazak Road Peshawar, Pakistan \\ Dr. Samra Kiran \\ Assistant Professor, City University of Science and Information Technology \\ Dalazak Road Peshawar, Pakistan \\ sk@cusit.edu.pk
}

\begin{abstract}
This work has tried to investigate the impact of microfinance on the development of SMEs). The primary data was collected through questionnaires from SMEs in Peshawar. The results show that microfinance plays a vital role in the revenue and profit growth of SMEs and reveals that SMEs with higher financial risk and lower levels of productivity are more likely to seek microcredit. Furthermore, the results suggest that firm characteristics including product innovation efforts and managerial and entrepreneurial attitudes are the key determinants of the likelihood of receiving microfinance. The main problems identified were lengthy documentation process, lack of information about the microcredit other security requirements.
\end{abstract}

Keywords: Microfinance, Small and Medium Enterprises, Microfinance Institutions, Micro Credit

\section{Introduction}

Microfinance helps to promote SMEs) worldwide. The aim of every country is to promote business and entrepreneurship activities in their country, as SMEs increase the employment ratio, reduce poverty level and improves the lifestyle of the people. In European countries SMEs are supported by a different financial institutions but, In Asia, most of the countries are in the developing stage so, they are to be more focused on SMEs compared to developed countries. Microfinance is the finance arrangement for working capital needs and other short-term needs of the business. Their kind of financeis beneficial for SMEs. The objective of microfinance is simply to introduce the systematic changing in financial systems in worldwide countries, the aim of the financing institutions is to provide microloans. Because these loans help then to run a small business in their country and remove the poverty from the country (Waheed-ur-Rehman, 2007).

Poor individuals require an assortment of financial services, not simply credit. Microfinance means building a budgetary framework that serves poor people. Microfinance is the strongest instrument to fight against poverty. Microfinance must pay for itself to achieve an expensive 
quantity of poor people. Microfinance is tired of building changeless neighborhood budgetary organizations. Interest rate roof making is harder for needy individuals to get credit. The part of the government is to empower financial services not to give them. The execution of SMEs has been noteworthy in creating economies. Distinctive creator's characteristics SMEs in an unexpected way. A portion of the creators separates them regarding capital resources while others based it on expertise and turnover. Jordan (1998) characterize SMEs that have less than 100 employees on a turnover of under 15 million euro. The United Nations Industrial Development Organization (UNIDO) characterize SMEs as far as a number of representative and arranges them in creating and created economies in an unexpected way.

As indicated by Pakistan's financial overview (2012-13), Pakistan's economy keeps on confronting challenges like vitality deficiencies, surges and rains, poor lawfulness circumstances, and a large group of other auxiliary obstacles that have kept down venture and development in the nation. The economy of Pakistan amid the most recent five years developed by and large at the rate of 2.9 percent for each annum. The mechanical area contains 20.9 percent of GDP having differentsubdivisions including power and gas, mining, producing, development, and quarrying and appropriation. Assembling area has a 13.2 percent share in GDP. The development of the assembling part is evaluated at 3.5 percent contrasted with the development of 2.1 percent a year ago. Microfinance institute performs a basic role in the economy to promote and extending small loans and other basic financial services to that person who has currently scarce capital. The microfinance is a vital solution and has some benefit of Microfinance i.e. access, better loan repayment rates, extending education, improve health and welfare, sustainability, job creation.

\section{Problem Statement}

SMEs are facing problems in Pakistan the main problem faced by SMEs, is the availability and benefits of lack of knowledge about Microfinance, SMEs owners or managers are unaware of benefits associated with Microfinance. The political stability, lack of funds, create problems for the SMEs, as we all know the aim of microfinance is to promote the SMEs because SMEs reduce poverty levels by generating employment, upgrading living standards. Microfinance is facing problems ranging from managerial to their inability to properly evaluate loan application and improper credit risk management which has resulted in a high degree of unpaid debt and consequently the closure of so many microfinancebanks in the recent past. It is against this that the subject matter is seen as an empirical problem worthy of being investigated.

\section{Research Questions}

- What is the impact of microfinance onSMEs 'development in Pakistan?

- What are thepotentialobstaclesfaced by SEMs in getting credit from microfinance institutions?

\section{Research Objectives}

- To investigate the role of microfinance in the development of SMEs in Pakistan.

- To identify problems faced by SMEs in getting credit from microfinance institutions.

\section{Significance of Research}

The aim of this research is to understand the function of microfinance and how they help to promote the growth of SMEs. The purpose of doing this research is to create awareness among the people about the microcredit funds availability in the marketplace. This will also help policymakers to design credit policies that are more favorable to SMEs. As in every country, SMEs play a beneficial role in the development of the economy. SMEs increase the rate of 
employment, decreases poverty from the country and generate the capital for the country, boost up the country activity, changing lifestyle in the country. Through microcredit opportunity, all the people are accessed and start their business easily. This work will also enrich the literature already available and guide new researchers in their research.

\section{LITERATURE REVIEW}

\section{Introduction}

Many financial experts suggest increasing the rate of SMEs in the economy. As they helping in the unemployment ratio. SMEs have no common definition in the world. The developing and developed countries are dealing with SME for their growth of the economy (Ohashi, 2007; Soraino \& Doborn, 2009; Sadi \& Henderson, 2010). The number of employees is the most widely recognized part of the meaning of SMEs. (Ardic, Mylenko \& Saltine, 2011). Bekele and Zeleke (2008) suggest four categories which affect long term growth, survival and viability of Micro Small and Medium Enterprise (MSME) which are- Factors that affect macroeconomics, approach to social capital, affectsthe internal performance of small business and enterprises and that which contribute to microfinance services.Mohammad (2015) suggests that in Saudi Arabia SMEs speak to over $90 \%$ of the enterprises giving $51 \%$ of employment in the private division and they contribute $22 \%$ of the GDP. The organization for economic cooperation and development (OECD) concluded that the significance of SMEs is generally perceived as a key part in making new employment and represents more than $95 \%$ of the firm's objectives will enhance the monetary social prosperity of individuals around the world. Almost of net occupations are made in SMEs, OECD nations OECD, 2006; Karadag, 2015).

Different analysts picked instead of supporting large enterprises and focused on their satisfactory situations. They opposed an expensivefirms with positive suggestions for poverty improvement. They also suggested that large projects misuse economies of scale, which can impact efficiency (Pack \& Westphal, 1986).The study of Asian Development Bank (2009) on SMEs in 13 nations getting capital is the best requirement for firm arrangement and development. SMEs' financing programs are just in ones, at the point SMEs regularly approach casual hotspots for their financing needs (Tanaka \& Molnar, 2008). In China that the local casual loan specialist tends to the center around the borrower's present activities, especially the extent of receivable, while formal money lenders, for example keeping money establishments to a great extent center around pest execution (Tanaka \& Molnar, 2008).

Different financing strategies for SMEs arise at end of the twentieth century, enabling economies to exploit opportunities and the most essential and the extensive part of world economies are the small firms that had increased numerous researchers to look for and tries to understand these organizations. Even the administration of every economy of the globe and especially those workplaces where improvement and understanding about these organizations are required (Hill \& McGowan, 1999).

\section{SMEs in Pakistan}

In Pakistan, SMEs division is not just the minor sharer (having little commitment) till yet in boosting the economy, actually, Pakistan's entire economy is exceedingly subject to the pace and profitability of SMEs. Out of Pakistan's 3.2 million enterprises, 95 percent are the individuals who have 99 representatives in the private sector and employ around 78 percent of not agriculture labor force. SMEs contribute above 25 percent of assembling merchandise and 30 percent of GDP. SMEs will be the principle wellspring of neediness decrease in Pakistan that will make the advancement for the nation in the future (Bizomer, 2009). 
Pakistan economic survey (2012-13) Pakistan's economy face challenges like vitality deficiencies, surges and rains, poor lawfulness circumstance, and a large group of other auxiliary hindrances that have kept down speculation and development in the nation. The economy of Pakistan amid the most recent five years developed all things considered at the rate of 2.9 percent for each annum. The mechanical division contains 20.9 percent of GDP having sub-segments: producing, development, mining and quarrying and power and gas dispersion. Assembling part has a 13.2 percent share in GDP. The development of the assembling part is evaluated at 3.5 percent contrasted with the development of 2.1 percent a year ago. According to State Bank of Pakistan (2009) \& Economic Survey of Pakistan (2009-10). The SME area in Pakistan contributes 30 percent in the GDP, alongside farming part gives 90 percent occupations, 80 percent of the non-rural workforce, makes 35 percent esteem option in the assembling business and includes 25 percent fares income in the national exchequer [up to US\$2.5 billion] (Qureshi, 2012).

\section{Growth and Services of SMEs by Microfinance}

Microfinance refers to the arrangement of monetary administrations custom-made to the prerequisites of low salary individuals like economized scale business visionaries, especially the conveyance of small credits, the arrangement of small advances, receipt of small investment funds stores and simple installment administrations required by smaller-scale business people and other poor individuals (USAID Prisms, 2005). Microfinance indicates little scale business or credit administrations which are made accessible to individuals working chose business running small enterprises in which products are fabricated, reprocessed, repaired or traded in provincial and additionally no rural areas (Stanley, 2008). Probability in Microfinance could be authoritative, administrative or money-related. Microfinance includes making an extensive variety of budgetary administrations accessible similar to stores, credits, exchanges and protection administrations to small businesses. It additionally includes making accessible budgetary administrations to a smallbusinesses that are generally not cooked for by the business banks (Thapa, 2007).Microfinance institutions (MFIs) evaluate the observing and control phases of the loaning procedure (Sheila, 2011).

Kolawole, (2013) states that microfinance banks help to deliver reserve funds in the economy, allure outside contributing offices, encourage enterprise and advance improvement in the economy. Okpugie, (2009) expressed that the high premium asked for by the microfinance banks has been seen to be the reason for disturbing default. Obisesan and Oyedele (2015) concluded that these casual credit foundations offer loans and funds to their individuals. Microfinance is more extensive than small scale credit as it includes reserve funds, credit, and protection among others (Kirkpatrick \& Maibo, 2002). The non-conventional formal Microfinance Institutions (MFIs) are working nearby with casual organizations. The improvement of the microfinance organizations came as an outcome of the powerlessness or hesitance of the customary banks to draw from the budgetary resources in the country regions (Onaolapo \& Oladejo, 2011). Akinlabi, Jegede,andKehinde (2011) argued that although the entire universe, the underprivileged are regularly exempted from the formal money related framework either incompletely in created nations or full exception in Less Developed Countries (LDCs). Microfinance program is proper when there are upgrades in credit availability particularly to those who need help dismissed by banks" aside from advance arrangement microfinance additionally give non-money related administrations, for example, preparing (Schreiner \& Colombet, 2001). Microfinance as the arrangement of budgetary administrations to poor people who are over the official neediness line 
and profoundly poor family units. Otero (1999).Microfinance administrations are given in view of the installment conduct of the borrower which demonstrates the capacity of the borrower to recoup the obligation (Ledgerwood, 1998).

\section{Theoretical Framework}

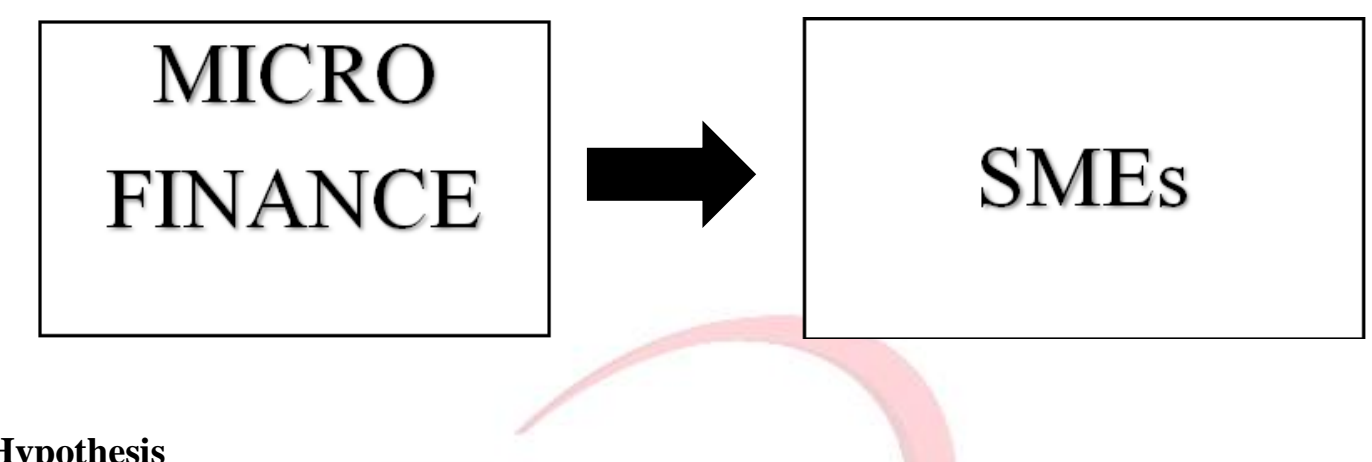

Hypothesis

H1: Microfinance has a significant impact on the performance of SMEs.

$\mathrm{H} 2$ : Microfinance has an insignificant impact on the performance of SMEs.

\section{Methodology}

This section highlights the research population, design, sample, data validity and reliability, data collection methods, data analysis, and techniques.

\section{Research Design}

This is a descriptive study. Primary data was collected through a questionnaire, a non-probability convenience sampling technique from 120 employees working in different SMEsof Peshawar.

\section{Results, Analysis,And Discussion}

\section{Data Analysis and Presentation}

The questionnaires were analyzed and prepare for coding. The statistical package for social sciences (SPSS) was used for further data analysis.

\section{Business Type}

Respondents were required to specify the nature of their businesses $51.7 \%$ indicate that the small business and remaining $48.3 \%$ of them isa medium business. The findings show that there was a proportional representation of the two categories of business.

Table 4.3: Business Type

\begin{tabular}{ccc}
\hline Business & Frequency & Percentage \\
\hline Small & 62 & $51.70 \%$ \\
Medium & 58 & $48.30 \%$ \\
Total & $\mathbf{1 2 0}$ & $\mathbf{1 0 0 \%}$ \\
\hline
\end{tabular}




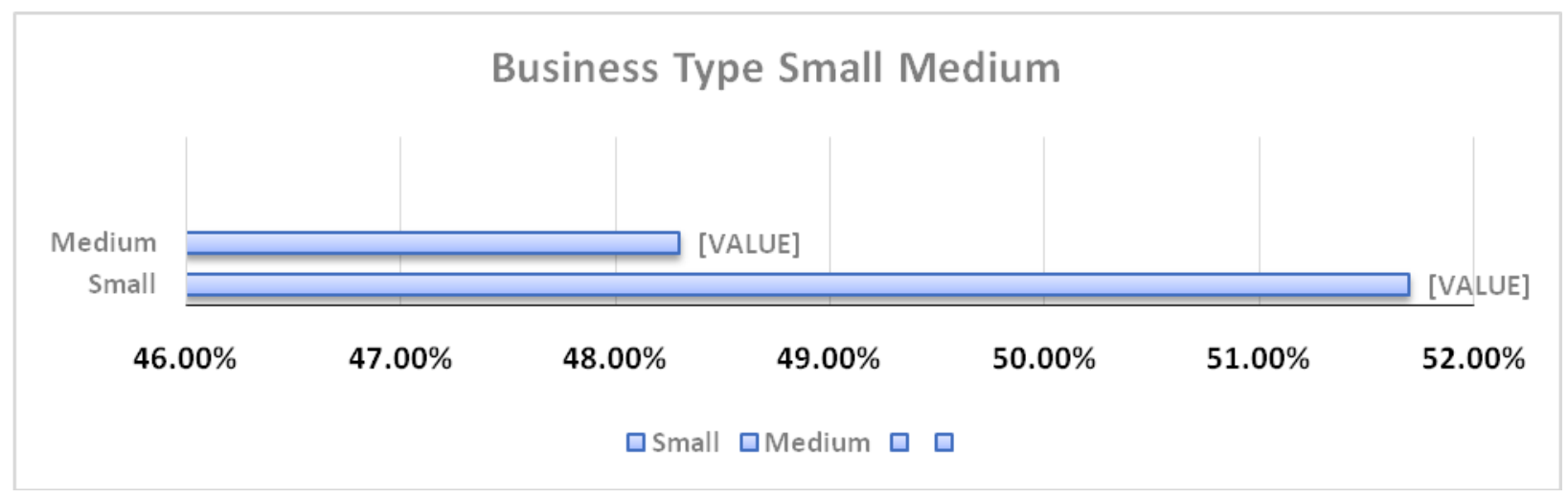

Figure 4.1: Business Type

Number of Employees

Respondent were required to specify the number of employees their business had.75.8\% of them indicate that they had 6-20 employees in their business and the remaining $24.2 \%$ of them indicate that they had 21-50 employees. The finding declares that most of the SMEs had few employees working for them attribute to the small scale of operation.

Table 4.4: Number of Employees

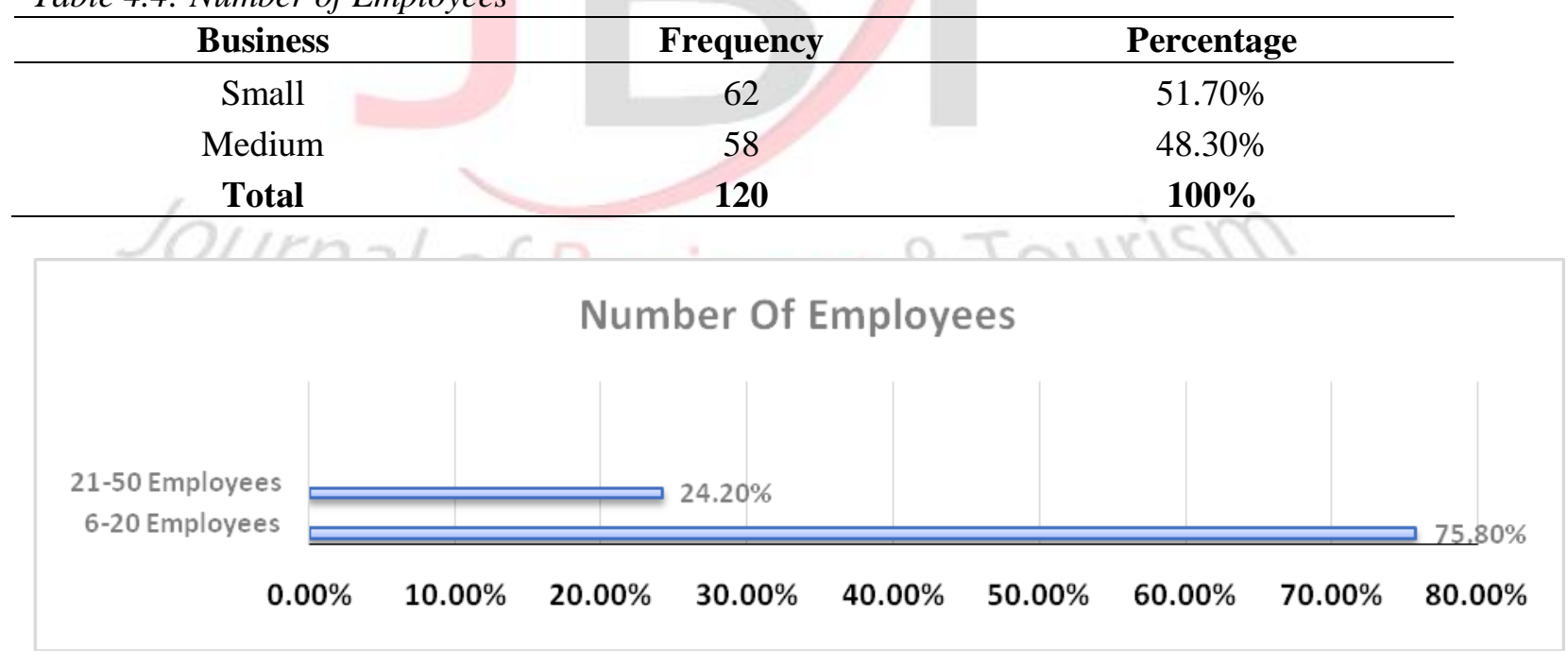

Figure 4.2: Number of Employees

\section{Period SMEs Had Been in Operation}

The result shows that 24.2\%)of the respondents in this study had been in operation for a period of fewer than 10 years. The 43.3 of them had been in operation for a period of between 11-20 years. Another $23.3 \%$ of them had been in operation for a period of between 21-30 years. And the remaining $9.2 \%$ of them had been in operation for a period of more than 30 years. This specifies that the majority of the SMEs had been in operation for long enough to facilitate them access credit. 
Table 4.5: Period SMEs Has Been in Operation

\begin{tabular}{ccc}
\hline Period & Frequency & Percentage \\
\hline 10 years or less & 29 & $24.20 \%$ \\
11-20 years & 52 & $43.30 \%$ \\
21-30 years & 28 & $23.30 \%$ \\
More than 30 years & 11 & $9.20 \%$ \\
Total & $\mathbf{1 2 0}$ & $\mathbf{1 0 0 \%}$ \\
\hline
\end{tabular}

\section{Periods SMEs Has Been In Operation}

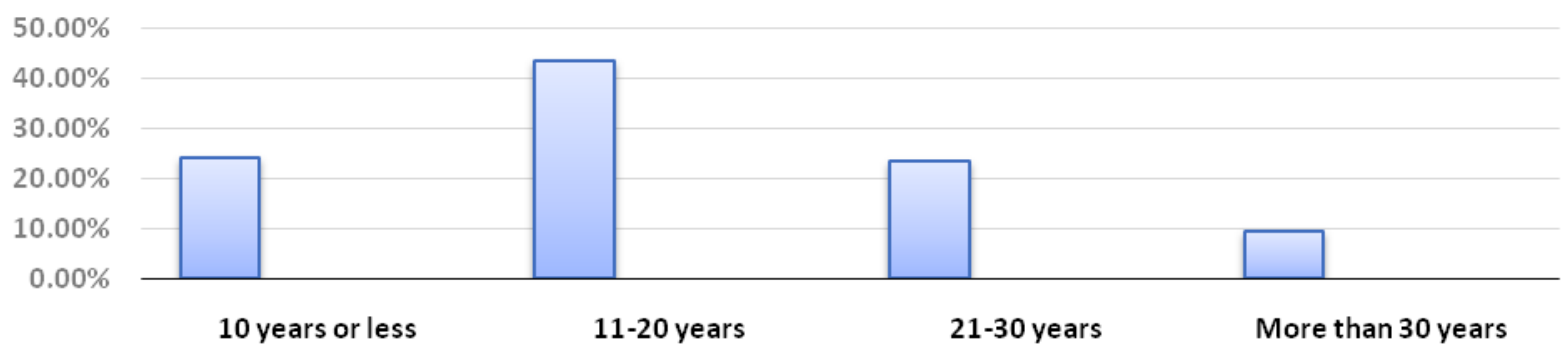

Figure 4.3: Period SMEs Has Been Operation

Availed Microfinance Opportunity

The result showsthat $40 \%$ of SMEs have availed microfinance opportunity and $40 \%$ of them not availed the microfinance opportunity and $20 \%$ of them don't know about the microcredits loans.

Table 4.6: Availed Microfinance Opportunity

\begin{tabular}{|c|c|c|}
\hline Microfinance Opportunity & Frequency & Percentage \\
\hline Yes & 48 & $40 \%$ \\
\hline No & 48 & $40 \%$ \\
\hline Don't know & 24 & $20 \%$ \\
\hline Total & $\mathbf{1 2 0}$ & $\mathbf{1 0 0 \%}$ \\
\hline
\end{tabular}

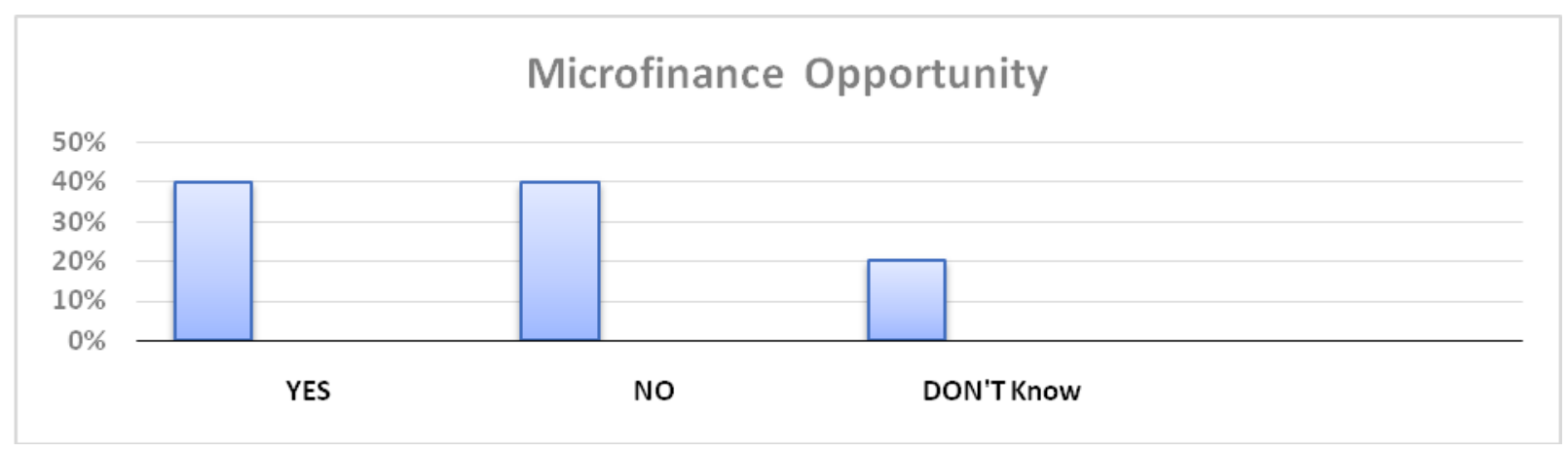

Figure 4.4: Availed Microfinance Opportunity 


\section{Sales Level before Getting Credit}

The result shows that $40.8 \%$ of the respondent were of the view that their sales level were low before getting credit.37.5\% indicate that they have a normal sale before getting microcredit. $12.5 \%$ of them indicate that their sales level is high before getting credit. And 9.2\% of them they don't know about microcredit loan.

Table 4.7: Sales before Getting Credit

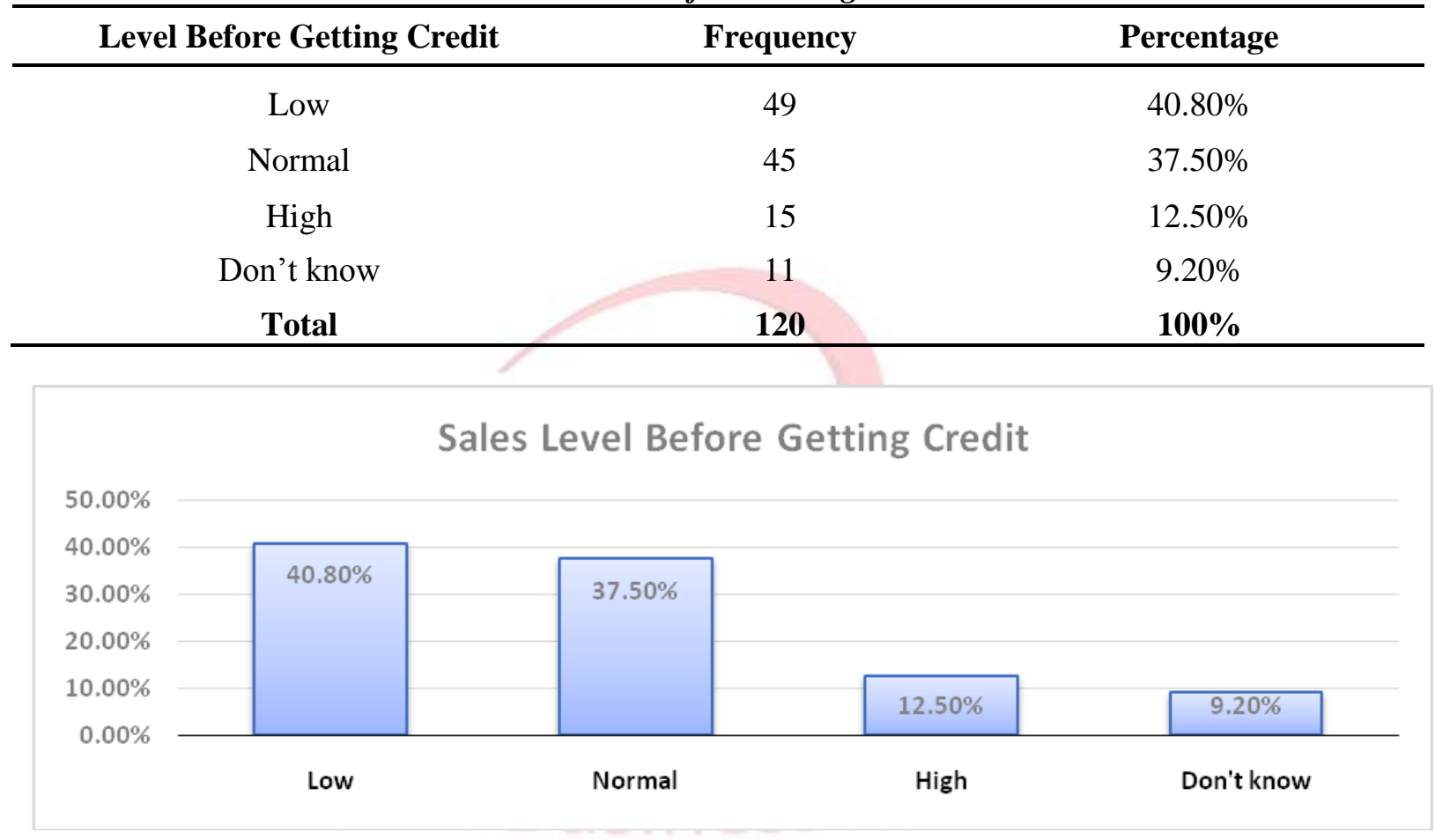

Figure 4.5: Sales Level before Getting Credit

Average Sales after Using Credit

Respondents were further required to indicate the average sales after using credit.5\% of the average sales were low after using microcredit.26.7\% had average sales normal after using microcredit.51.7\% of them had high average sales after using microcredit. And $16.7 \%$ of them they don't know about the microcredit.

Table 4.8: Average Sales after Using Credit

\begin{tabular}{|c|c|c|}
\hline Average Sales After Using Credit & Frequency & Percentage \\
\hline Low & 6 & $5.00 \%$ \\
\hline Normal & 32 & $26.70 \%$ \\
\hline High & 62 & $51.70 \%$ \\
\hline Don't know & 20 & $16.70 \%$ \\
\hline Total & $\mathbf{1 2 0}$ & $\mathbf{1 0 0 \%}$ \\
\hline
\end{tabular}




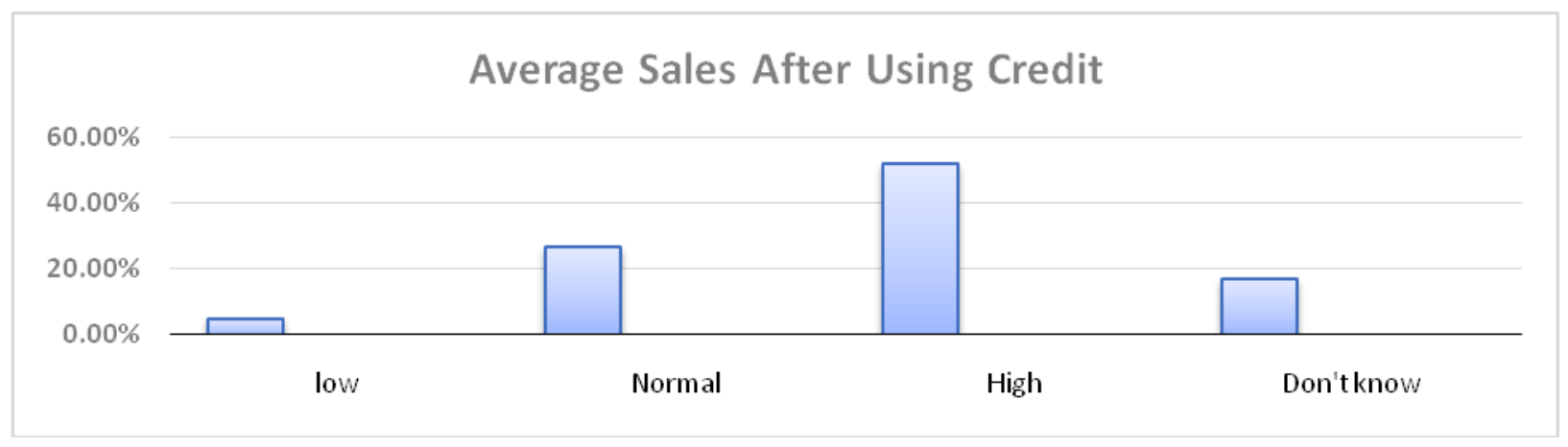

Figure 4.6: Average Sales after Using Credits

\section{Sales Level after Using Microcredit}

The results show that $36.7 \%$ of the respondents indicate that after using microcredit their sales level is highly increased $4.2 \%$ of them indicate that after using microcredit their sales level are highly decreased.31.7\% indicate that after using of microcredit there is no change in sales.27.5\% indicate that their sale level is improved after using microcredit.

Table 4.9: Sales Level after Using Microcredit

\begin{tabular}{ccc}
\hline Sales After Getting Credit & Frequencies & Percentage \\
\hline Highly increased & 44 & $36.70 \%$ \\
Highly decreased & 5 & $4.20 \%$ \\
No change & 38 & $31.70 \%$ \\
Improved & 33 & $27.50 \%$ \\
Total & $\mathbf{1 2 0}$ & $\mathbf{1 0 0 \%}$ \\
\hline
\end{tabular}

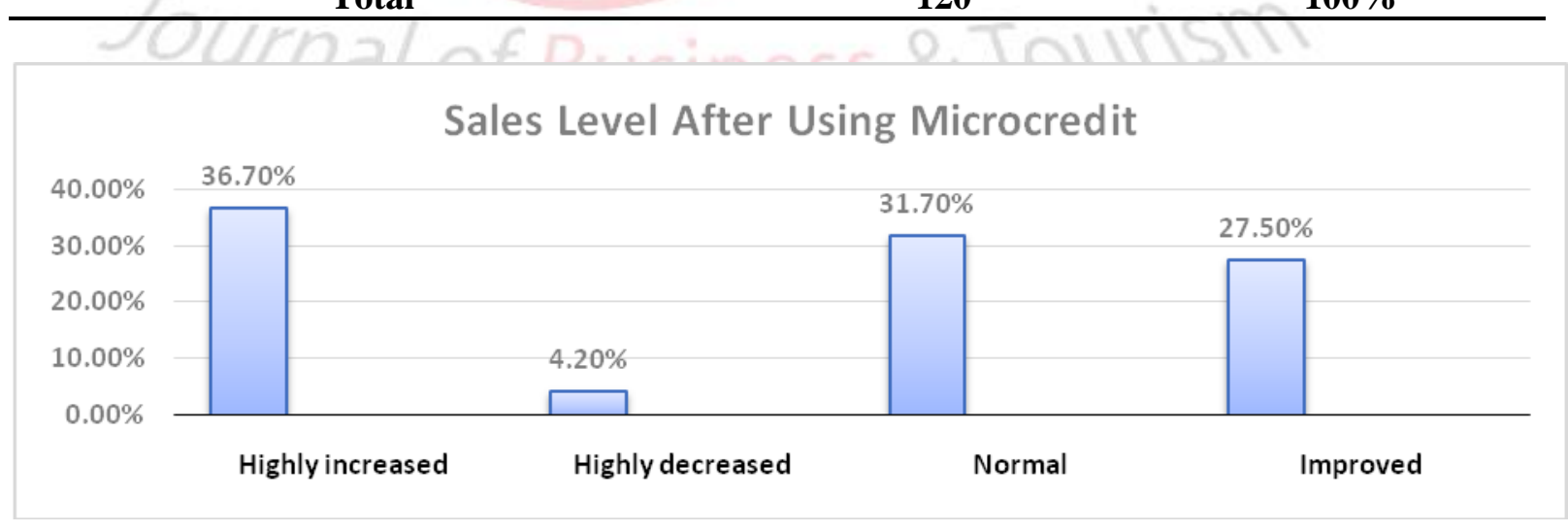

Figure 4.7: Sales Level after Using Microcredit

\section{Microfinance Contribute to Your Annual Profits by Using Microcredits}

The result shows that $69.2 \%$ of the respondents indicate that microfinance contributes to our annual profits by using microcredits. And the remaining $30.8 \%$ concluded that there is no change in thier annual profits by using microcredits. 
Table 4.10: Microfinance Contribution in Annual Profits

\begin{tabular}{ccc}
\hline Microfinance Contribute & Frequencies & Percentage \\
\hline Yes & 83 & $69.20 \%$ \\
No & 37 & $30.80 \%$ \\
Total & $\mathbf{1 2 0}$ & $\mathbf{1 0 0 \%}$ \\
\hline
\end{tabular}

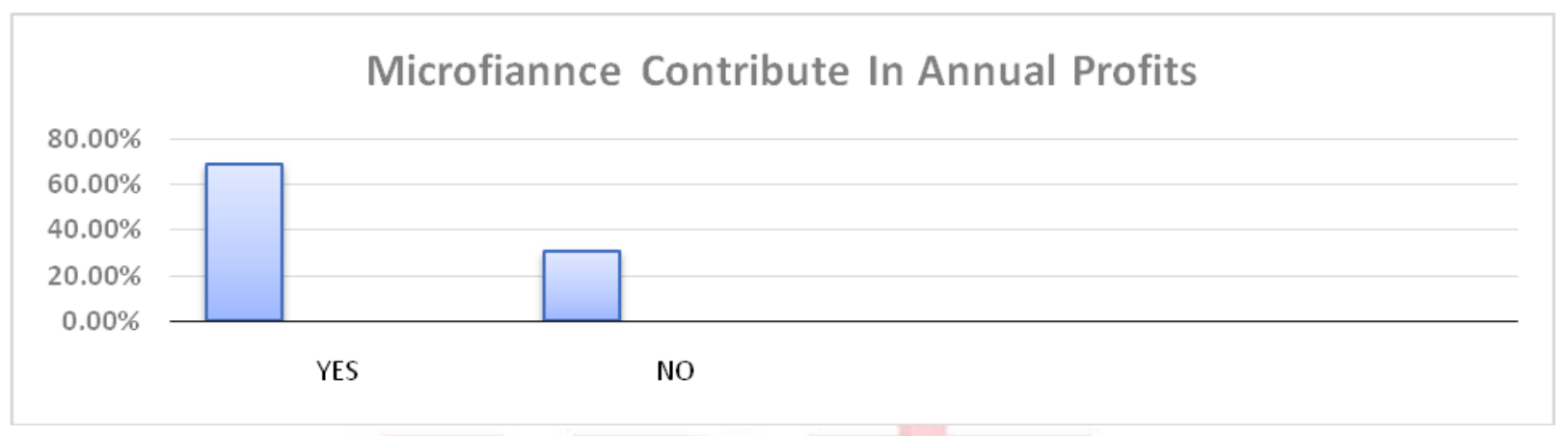

Figure 4.8: Microfinance Contribute to Annual profits

\section{Firm Total Assets Increase Using of Microcredits}

The result shows that $16.7 \%$ of the respondents indicates that the firm total assets increase by using microcredits are very little extent, $20.8 \%$ of them indicated little extent.19.2\% suggest to some extent, $28.3 \%$ concluded a great extent. And the remaining $15.0 \%$ of them indicate that there isa very great extent increase in the firm total assets by using microcredits.

Table 4.11: Firm Total Assets Increase Using of Microcredit

\begin{tabular}{ccc}
\hline $\begin{array}{c}\text { Firm Assets Increase Using of } \\
\text { Microcredits }\end{array}$ & Frequency & Percentage \\
\hline Very little extent & 20 & $16.70 \%$ \\
Little extent & 25 & $20.80 \%$ \\
Some extent & 23 & $19.20 \%$ \\
Great extent & 34 & $28.30 \%$ \\
Very great extent & 18 & $15.00 \%$ \\
Total & $\mathbf{1 2 0}$ & $\mathbf{1 0 0 \%}$ \\
\hline
\end{tabular}




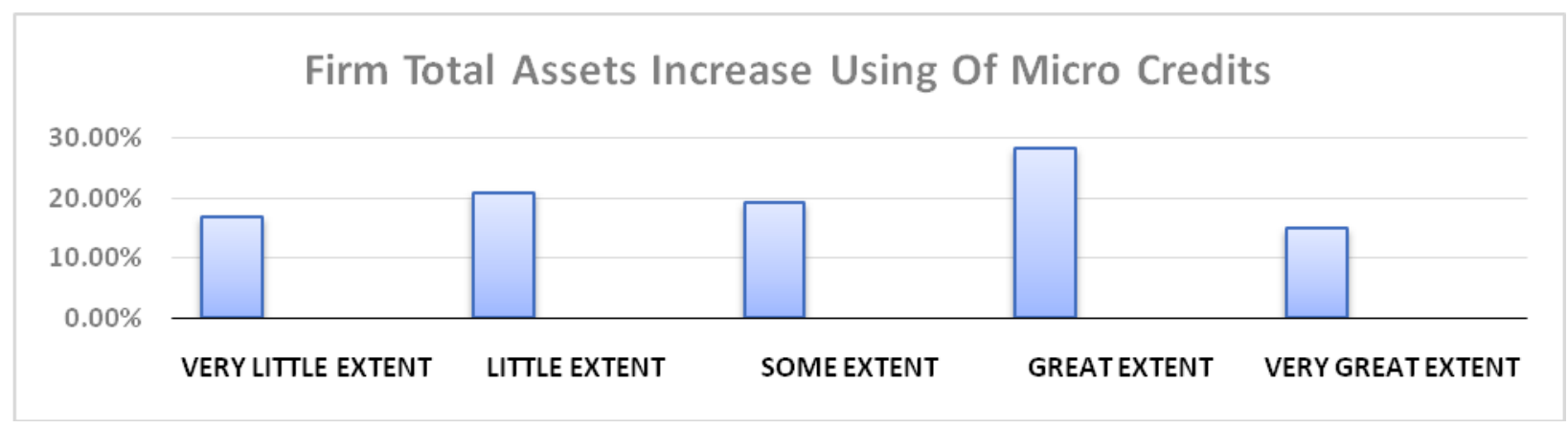

Figure 4.9: Firm Total Assets Increase Using of Microcredit

\section{Microcredit Have a Role in the Growth of Sale Level of SMEs}

The result shows that $8.3 \%$ of them indicated that there is avery little extent of the growth of the sale level of SMEs by the using of microcredit. $21.7 \%$ indicate little extent, $24.2 \%$ of them suggestssome extent, $27.5 \%$ suggests that agreat extent, and $18.3 \%$ of them suggest that microcreditto a great extent impact the growth of sale level of SMEs.

Table 4.12: Microcredit Have a Role in the Growth of Sale Level of SMEs

\begin{tabular}{ccc}
\hline Growth of Sale Level & Frequency & Percentage \\
\hline Very little extent & 10 & $8.30 \%$ \\
Little extent & 26 & $21.70 \%$ \\
Some extent & 29 & $24.20 \%$ \\
Great extent & 33 & $27.50 \%$ \\
Very great extent & 22 & $18.30 \%$ \\
Total & $\mathbf{1 2 0}$ & $\mathbf{1 0 0 \%}$ \\
\hline
\end{tabular}

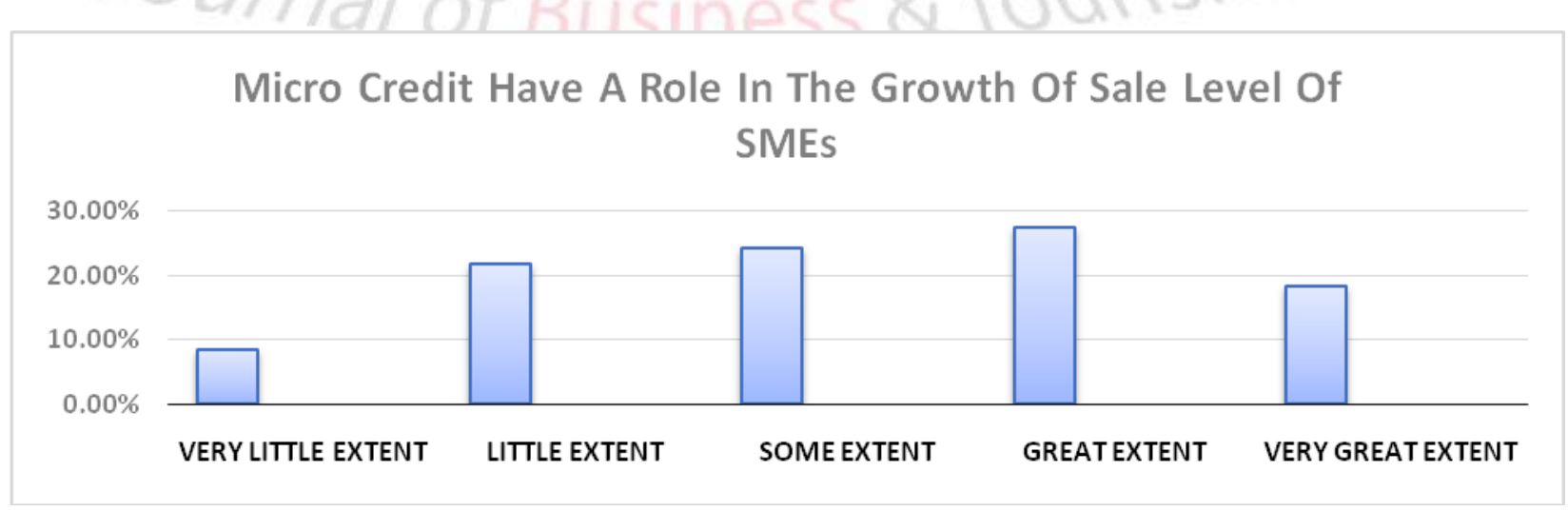

Figure 4.10: Microcredit Have a Role in the growth of Sale Level of SMEs

Microcredit Influence Employment Level with In the SMES Sector

The result shows that $10.8 \%$ of them are very little extent to Microcredit influence employment level with in the SMEs sector.18.3\% were little extent to Microcredit influence employment level with in the SMEs sector. $34.2 \%$ they are some extent to employment level with in the SMEs 
sector.15.8\% are of them are great extent to Microcredit influence employment level with in the SMEs sector. And the remaining $20.8 \%$ are very great extent to Microcredit influence employment level with in the SMEs sector.

Table 4.13: Microcredit Influence Employment Level with in the SMEs Sector

\begin{tabular}{ccc}
\hline Employment Level with In the SMES Sector & Frequency & Percentage \\
\hline Very little extent & 13 & $10.80 \%$ \\
Little extent & 22 & $18.30 \%$ \\
Some extent & 41 & $34.20 \%$ \\
\hline
\end{tabular}

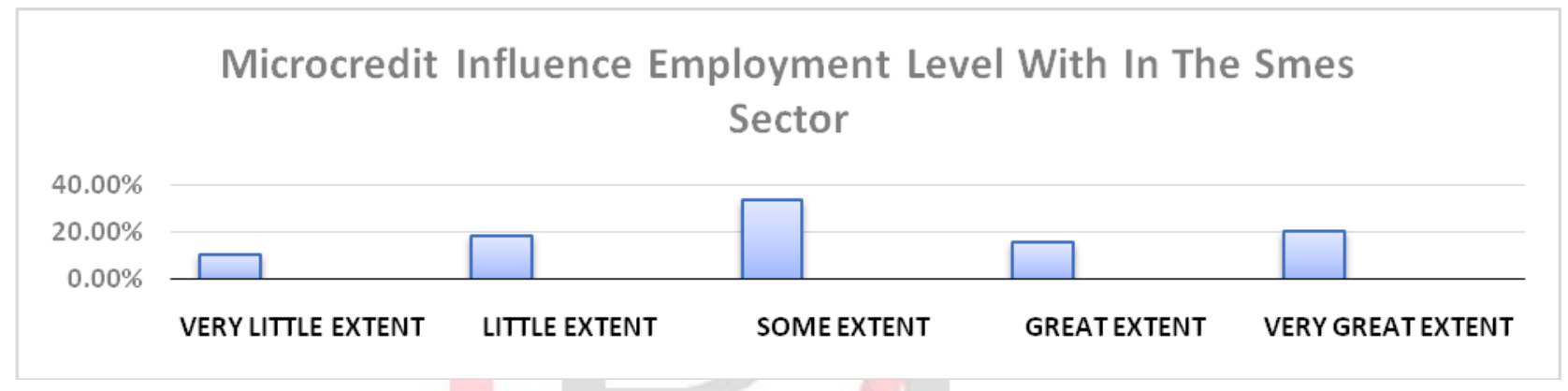

Figure 4.11: Microcredit influence Employment Level with in the SMEs Sector

Use of Microcredit Influence the Creation of More SMEs

There results show that $11.7 \%$ of them are little extent to use of microcredit influence the creation of more SMEs.22.5\% of them little extent to use of microcredit the creation of more SMEs.20.0\% indicate that they were some extent to microcredit influence the creation of more SMEs. 22.5\% are great extent and $23.3 \%$ of them are very great extent Use of microcredit influence the creation of more SMEs.

Table 4.14: Use of Microcredit influence the Creation of More SMEs

\begin{tabular}{ccc}
\hline Microcredit Influence the Creation of More SMEs & Frequency & Percentage \\
\hline Very little extent & 14 & $11.70 \%$ \\
Little extent & 27 & $22.50 \%$ \\
Some extent & 24 & $20.00 \%$ \\
Great extent & 27 & $22.50 \%$ \\
Very great extent & 28 & $23.30 \%$ \\
Total & $\mathbf{1 2 0}$ & $\mathbf{1 0 0 \%}$ \\
\hline
\end{tabular}




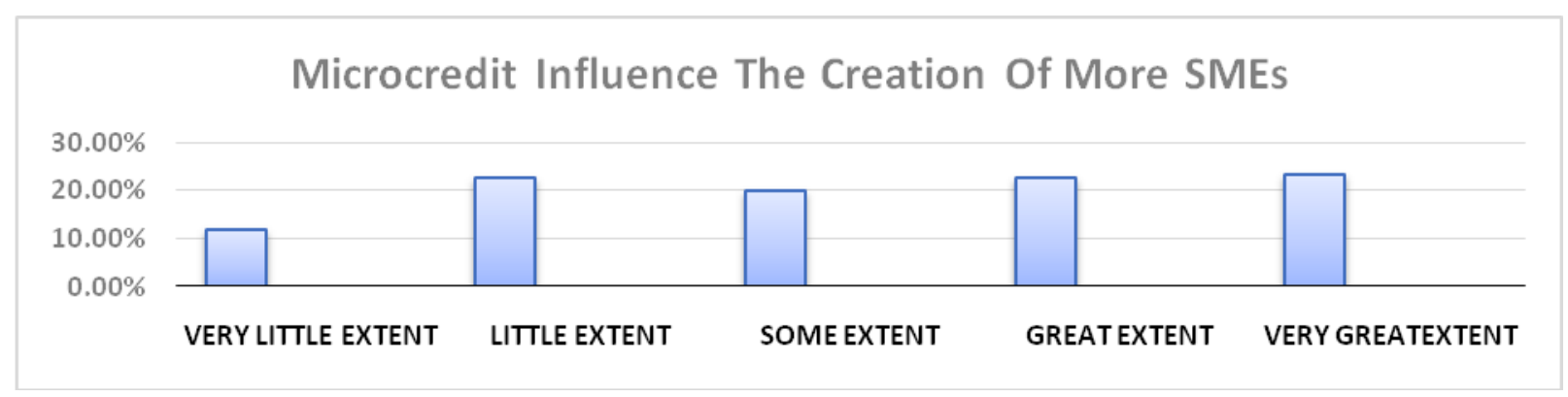

Figure 4.12: Microcredit Influence the Creation of More SMEs

Do Loan Granted Lead to Growth in Their Businesses?

The results show that $12.5 \%$ indicate that to a very little extent the loan granted leads to growth in their businesses.16.7\% responded that to a little extent microfinance contributed in the growth in their businesses. $24.2 \%$ shows to some extent it leads to growth in their businesses.30.8\% shows that to a great extent these loans contributed in the growth of their business. And remaining $15.8 \%$ are very great extent do loan granted lead to growth in their businesses.

Table 4.15: Do Loan Granted Lead to Growth in their Business

\begin{tabular}{ccc}
\hline $\begin{array}{c}\text { Loan Granted Lead to Growth in Their } \\
\text { Businesses }\end{array}$ & Frequency & Percentage \\
\hline Very little extent & 15 & $12.50 \%$ \\
Little extent & 20 & $16.70 \%$ \\
Some extent & 29 & $24.20 \%$ \\
Great extent & 37 & $30.80 \%$ \\
Very great extent & 19 & $15.80 \%$ \\
Total & $\mathbf{1 2 0}$ & $\mathbf{1 0 0 \%}$ \\
\hline
\end{tabular}

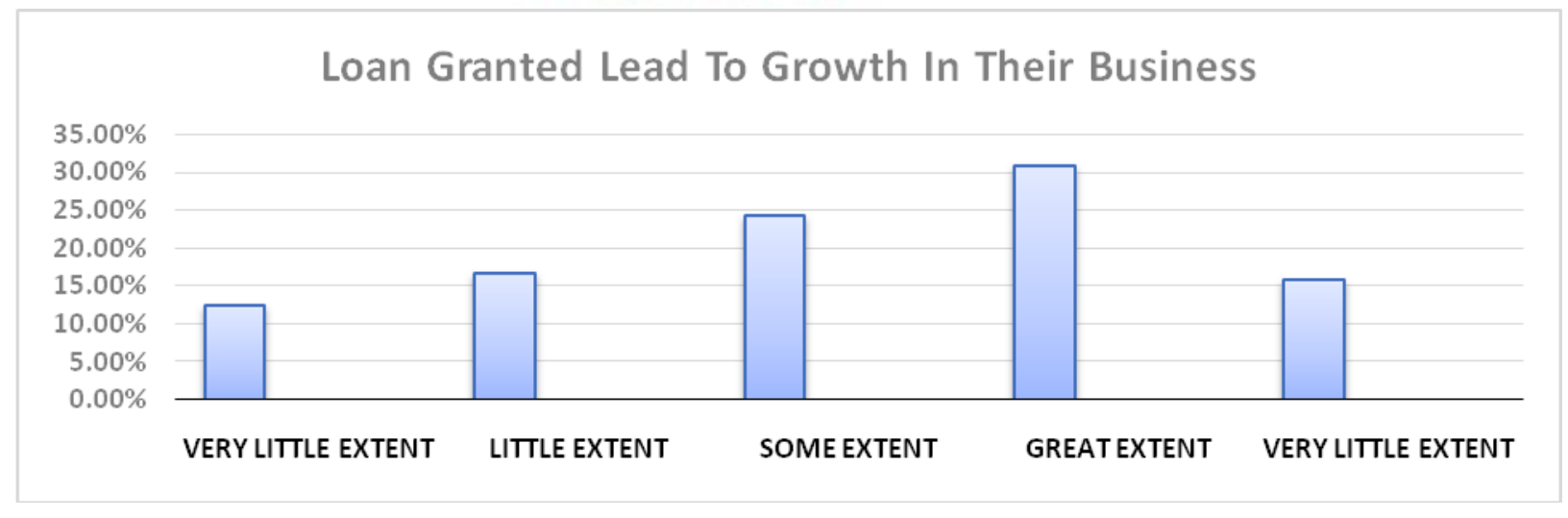

Figure 4.13: Do Loan Granted Lead to Growth in their Business 


\section{Do Client Use All Loan Granted for Business Activities}

The results showthat $11.7 \%$ of the respondents indicate that they used loan funds to very little extent, $21.7 \%$ shows a little extent,20.8\% shows to some extent, $22.5 \%$ of them are great extent, $23.3 \%$ are very great extentin their business activities.

Table 4.16: Client Use All Loan Granted forBusiness Activities

\begin{tabular}{ccc}
\hline Client Use All Loan Granted for Business & Frequency & Percentage \\
Activities & 14 & $11.70 \%$ \\
Very little extent & 26 & $21.70 \%$ \\
Little extent & 25 & $20.80 \%$ \\
Some extent & 27 & $22.50 \%$ \\
Great extent & 28 & $23.30 \%$ \\
Very great extent & $\mathbf{1 2 0}$ & $\mathbf{1 0 0 \%}$ \\
Total &
\end{tabular}

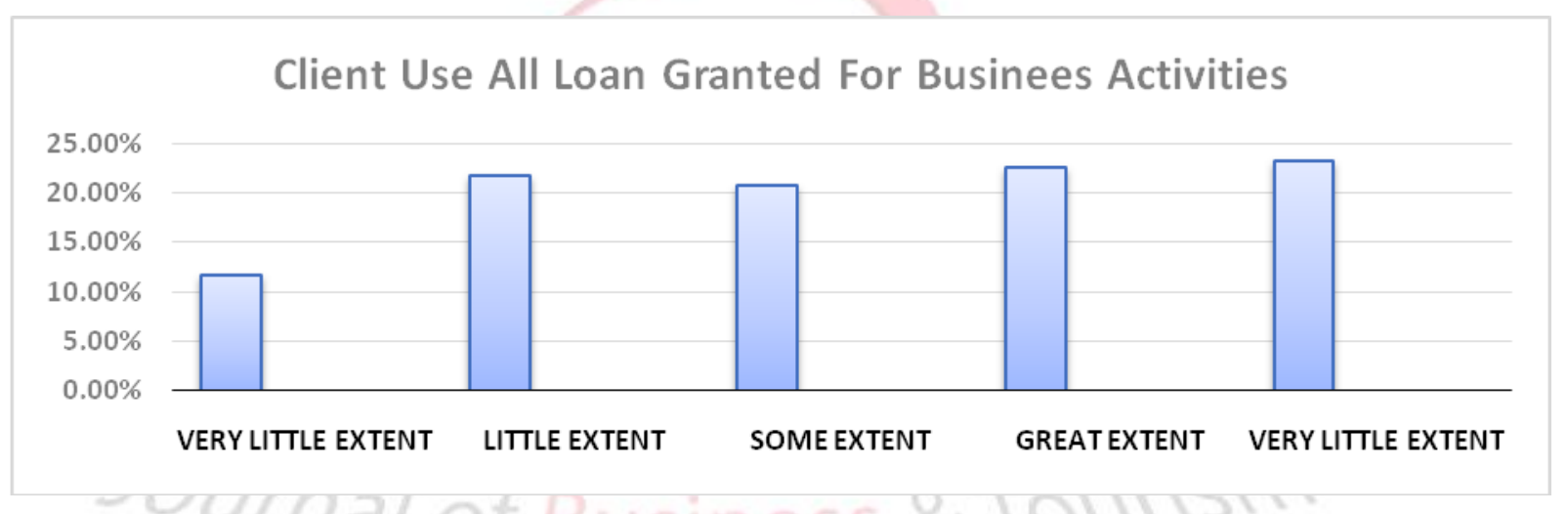

Figure 4.14: Client Use All Loan Granted 4for Business Activities

What Activities Do You Know Client Use the Loan For?

The results show that $25.0 \%$ indicate that loan use their personal activities $10.0 \%$ of them used to start a new business $25.8 \%$ indicate that they used it for expansion of their business activities and the $39.2 \%$ of them they don't know about what other activity to use the loan.

Table 4.17: What Activities Do You Know Client Use the Loan For

\begin{tabular}{ccc}
\hline Client Use the Loan For & Frequency & Percentage \\
\hline Personal use & 30 & $25.00 \%$ \\
Start new business & 12 & $10.00 \%$ \\
Expend in business activities & 31 & $25.80 \%$ \\
Don't know & 47 & $39.20 \%$ \\
Total & $\mathbf{1 2 0}$ & $\mathbf{1 0 0 \%}$ \\
\hline
\end{tabular}




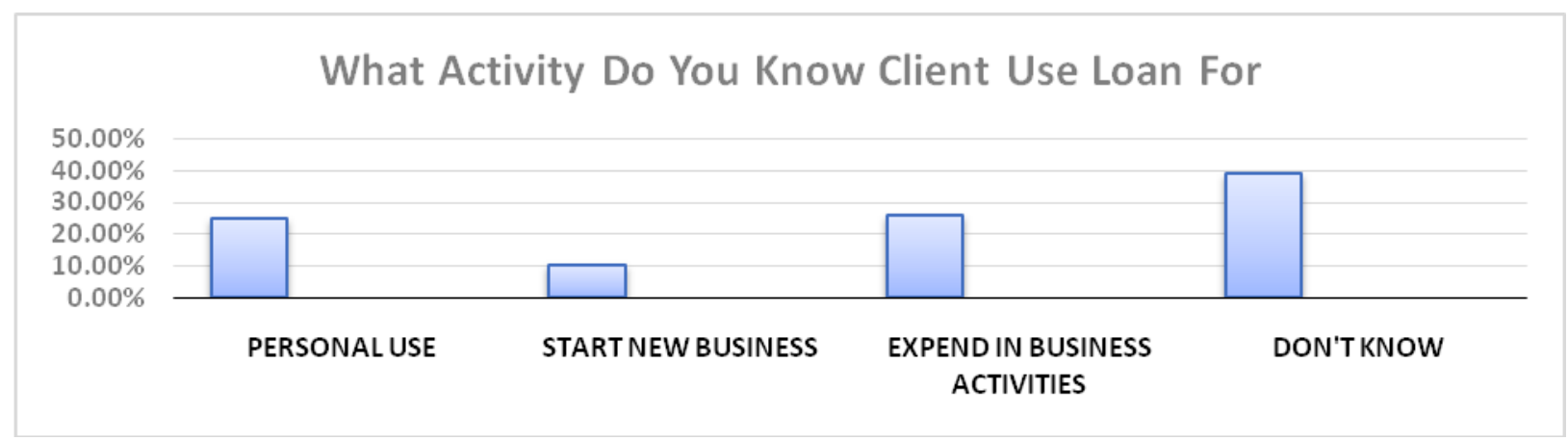

Figure 4.15: What Activities Do You know Client Use the Loan For

\section{How Credit Misappropriation Can Be Avoided}

The results show that the Respondents were avoid the misappropriation of credit $20.0 \%$ of them conclude that there is a lengthy process. $20.8 \%$ of them indicate that to take a high security. $16.7 \%$ indicate that there is very high risk to avoid misappropriation. $42.5 \%$ they are don't know about them.

Table 4.18: How Credit Misappropriation Can Be Avoided

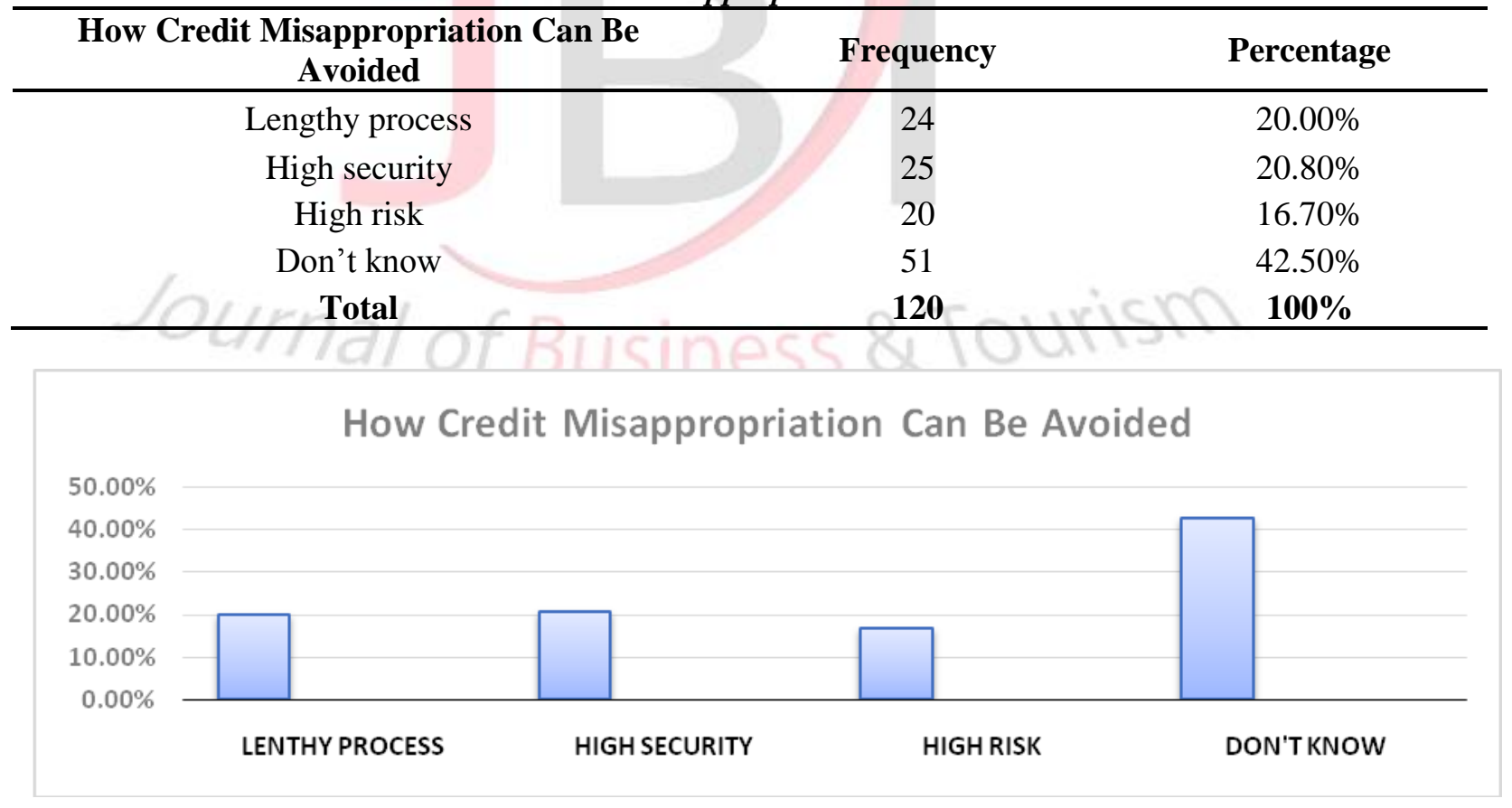

Figure 4.16: How Credit Misappropriation Can Be Avoided

Improve Accessibility of Microcredit by SMEs

The results show that improve the accessibility of microcredit there the $17.5 \%$ indicate that adopting good policies to improve accessibility of microcredit by SMEs. 16.7\% of them are awareness about loan to improve accessibility of microcredit by SMEs. 13.3\% indicate that its 
low markup to improve accessibility of microcredit by SMEs. And the remaining $52.5 \%$ they are don't know about to improve accessibility of microcredit by SMEs.

Table 4.19: Improve Accessibility of Microcredit by SMEs

\begin{tabular}{ccc}
\hline Improve Accessibility of Microcredit by & Frequency & Percentage \\
SMEs & 21 & $17.50 \%$ \\
\hline Adopting good policies & 20 & $16.70 \%$ \\
Awareness about loan & 16 & $13.30 \%$ \\
Low markup & 63 & $52.50 \%$ \\
Don't know & $\mathbf{1 2 0}$ & $\mathbf{1 0 0 \%}$ \\
Total & &
\end{tabular}

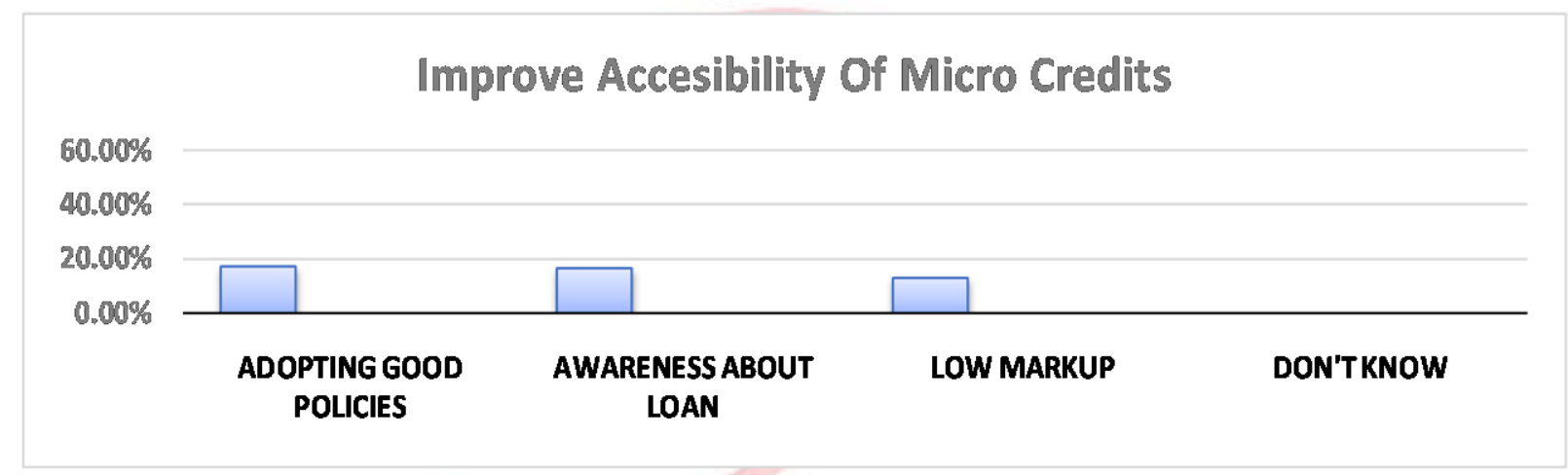

Figure 4.17: Improve Accessibility of Microcredit

\section{Findings, Conclusion and Recommendations}

\section{Findings}

This work had tried to access the relationship between microcredit and the growth of SMEs in Peshawar.51.7\% of the business were considered small and the remaining $48.3 \%$ of them are medium hence relative representation the two categories of business. Majority $75.8 \%$ of them had 6-20 employees are attributable to their small business. And remaining 24.2\% of them had 21-50 employees are there in medium business. Most of their $24.2 \%$ businesses had been operate in business for a time of period of 10 years or less than. Another $43.3 \%$ businesses had been in business for a period of 11-20 years. And 23.3\% businesses of them had been operate in a business for a time period of between 21-50 years. And the remaining 9.2\% businesses had been operate since for more than 30 years. Which was sufficiently long for them to assemble a financial record. In SMEs there a $40 \%$ of them they availed a microfinance opportunity and $40 \%$ of them they can't availed the microfinance opportunity. The remaining they don't know about the micro credit loan.

Following major findings are settled. Access of credit accordingly led to increase in sales level. $40.8 \%$ of the respondents' opinion that before getting credit their sale level is low. $37.5 \%$ SMEs their sales are normal before getting credit. $12.5 \%$ business their sale level is high before getting credit. And the remaining 9.2\% they don't know about the approximate sales level before getting credit. After using a microcredit 5\% of them indicate that their average sale is low. $26.7 \%$ conclude that after using a credit their average sales are normal. And 51.7\% they indicate that 
after using a microcredit their average sale is high. The remaining $16.7 \%$ they don't know about their average sale after using micro credit. $69.2 \%$ of them indicate that yes microfinance contribute to our annual profits by using microcredits. And the remaining $30.8 \%$ concluded that there is no change in our annual profits by using microcredits. $16.7 \%$ of them indicate that the firm total assets increase by using microcredits are very little extent. $20.8 \%$ of them indicated that the firm total assets increased by using microcredit are little extent.19.2\% the firm total assets by using microcredits are some extent. $28.3 \%$ concluded that the firm total assets by using microcredits are great extent. And the remaining $15.0 \%$ of them indicate that there is very great extent the firm total assets by using microcredits. Microfinance avoid the misappropriation $20.0 \%$ conclude that there is a lengthy process. $20.8 \%$ of them indicate that to take a high security. $16.7 \%$ indicate that there is very high risk to avoid misappropriation. $42.5 \%$ they are don't know about them. In SMEs businesses different activities client use the loan. respondents $25.0 \%$ indicate that loan use as our personal activities $10.0 \%$ of them to start a new business $25.8 \%$ indicate that take a loan and expend in our business activities and the $39.2 \%$ of them they don't know about what other activity to use the loan.

\section{Conclusion}

This study investigates the impact of microfinance on the performance of SMEs in Pakistan. SMEs perform a vital role in the economy. A survey was conducted through self-administered questionnaire from Peshawar. The study suggests that different firms who take microcredit from the microfinance bank and other sources, contribute significantly in the economic development and in reducing unemployment and poverty from the country. SMEs are struggling to for the access of microcredit in country like Pakistan. However, microfinance instrument seems to promote Pakistan's SMEs in different stages of a business life. The study finds that many businesses in the stage of starting-up have funded by owner's resources. Microfinance is mostly used when businesses intends to grow. The businesses use the microcredit influences the creation of more new SMEs in the country because the microcredit funds helps in generating the initial capital for new SMEs. The major difficulties recognized by the SMEs is lengthy documentation process, lack of information about the microcredit and other security requirements.

\section{Recommendations}

The researcher also recommends that the government should increase their efforts in encouraging microfinance banks and institutions to support the small businesses. The researcher also recommends that the Microfinance institutions should increase the number of SME owners trained on financial management by employing field agents to sensitize the business owners on the benefits of financial skills and also gather data on small medium enterprises to reduce adverse selection. The researcher would also like to recommend that Microfinance Institutions provide role models to small and medium enterprises as they can guide them on how to succeed in business. The researcher would also like to recommend to the Microfinance Institutions to Increase the number of savings accounts held by SMEs as savings was very important to their growth.

\section{References}

Abor, J. \& Quartey, P. (2010). Issues in SME Development in Ghana and South Africa. International Research Journal of Finance and Economics. (39), 218-228.

Acha, I.A. (2012). Microfinance Banking in Nigeria: Problems and Prospects. International Journal of Finance and Accounting.(1), 106-111. 
Ademu, W.A. (2012). Finance for the Poor: An Assessment of the Performance of Microfinance Institutions in Nigeria.An International Multidisciplinary Journal Ethiopia.(6), 312-325.

Alasrag, H. (2007). The Future of SMEs in Egyptian Economy.

Al-Disi, E. O. (2010). Developmental role for Waqf to support entrepreneurship and small and Medium enterprises. Dubai International conference.

Al-Wugayan, A. \& Alshimmiri, T. (2010). Encouragement of Entrepreneurship in Affluent Economies: The Case of Kuwait. International Business \& Economics Research Journal. 9(6), 34-48.

Angioloni, S. \& Kudabaev, Z., Ames, G. \& Werzstein, M. (2013). Micro-credit impact in Kyrgyzstan: A study case. Southern Agricultural Economics Association.(23).

Arafat, M. A. \& Ahmed, E. (2012). Managing Human Resources in Small and Medium Enterprises (SMEs) in Developing Countries: A Research Agenda for Bangladesh SMEs. Ardic, O. P. \& Mylenko, N. \& Saltane, V. (2011). Small and medium enterprises: a crossCountry Analysis with a new data set. World Bank Policy Research Working Paper Series. Asian Association of Management Organizations, (AAMO) (2007). SMEs in Asian Region Harnessing the Growth Potential, AAMO, New Delhi.

Asian Development Bank (2009). Enterprises in Asia: Fostering Dynamism in SMEs: Key Indicators for Asia and the Pacific 2009: Special Chapter, Asian Development Bank, Manila. Beaver, G., \& Prince, C. (2004). Management, strategy and policy in the UK small business Sector: A critical review. Journal of Small Business and Enterprise Development. 11(1), 34-49. Beck, T.\& Kunt, A. (2006). Small and medium-size enterprises: Access to finance as a growth Constraint. Journal of Banking \& Finance. 30(11), 2931-2943.

Berger, A. \& Udell, G. (1995).Relationship lending and lines of credit in small firm finance. Journal of Business. 68(3), 351-382.

Bizomer, (2009). Role of the SMEs in Pakistan. www.bizomer.com/role-of-smes-inpakistan.html.

Bolton, J.E. (1971). Report of the committee of Inquiry on small firms. London: HMSO.

Brealey, R \& Myers, S. (2003). Principles of Corporate Finance, International Edition. Chicago: McGraw Hill Canadian Federation of Agriculture.

Central Bank of Nigeria (2005) Microfinance, Regulatory \& Supervisory framework for Nigeria.http://www.cenbank.org.

Chittithaworn, C. \& Islam, A. \& Keawchana, T. \& Yusuf, D.H. (2011). Factors affecting

Business Success of small \& medium enterprises (SMEs) in Thailand. Asian Social Science. 7(5), 180-190.

Cooper, N (2012). The impact of microfinance service on the Growth of small and medium

Enterprises in Kenya. Unpublished MBA project, University of Nairobi.

Cowling, M., Liu, W. \& Ledger, A. (2012). Small business financing in the UK before and

During. The current financial crisis. International Small Business Journal. 30(7), 778-800.

Daniel, C. Hardy 2001. "Bank Reform \& Bank Efficiency in Pakistan," IMF Working Paper. WP/01/138.

Economic and Social Commission for Asia and the Pacific, (ESCAP) (2012). Financing a

Business, in Abe, M. Troilo, M. Juneja, J. S \& Narain,S. (Eds). Policy Guide book for SME Development in Asia and the Pacific. Chapter 5, United Nations, New York, NY.

Harvie, C\& Lee, B. C. (2002). East Asian SMEs: Contemporary Issues and Developments- 
An Overview. The role of SMEs in national economies in East Asia. 1-9.

Hill, J., \& McGowan, P. (1999). Small business and enterprise development: questions about Research methodology. International Journal of Entrepreneurial Behavior \& Research. 5(1), 5-18. http://dx.doi.org/10.1108/13552559910259829.

Jegede, C.A. Kehinde, J. \& Akinlabi, B.H. (2011). Impact of Microfinance on Poverty alleviation.

In Nigeria: An Empirical Investigation. Journal of Humanities \& Social Science. Journals Bank Inc.

John, N.N. \& Onwubiko, N.D. (2013). Problems of Microcredit among Microenterprises in Nigeria. Research Journal of Finance and Accounting.24(6), 29-41.

Karadag, H. (2015). Financial Management Challenges in Small and Medium Sized.

Enterprises: A Strategic Management Approach. EMAJ: Emerging Markets Journal.5(1), 26-40.

Kayanula, D. \& Quartey, P. (2000). The Policy Environment for Promoting Small and MediumSized Enterprises in Ghana and Malawi. Finance and Development Research Programmed. Working Paper Series. Paper No. 15, IDPM, University of Manchester. Khandker, S.R. Samad, H. A \& Ali, R. (2013). Does access to finance matter in Microenterprise Growth Evidence from Bangladesh. The World Bank Policy Research Working Paper No. 6333, Washington, DC.

Kirkpatrick, C. \& Maibo. S.M. (2002). The Implications of the evolving Microfinance agenda for Regulatory and Supervisory Policy. Development Policy Review.

Kolawole, S. (2013). Role of microfinance in Nigeria economy.

Koutsoyyiannis, J. (1982). The Impact of Internal Factors on the Export Success of Dutch Small.

Madugu A.J. \& Bzugu, P.M. (2012). The Role of Microfinance Banks in Financing Agriculture In Yola North Local Government Area. Adamawa State, Nigeria. Global Journal of Science Frontier Research Agriculture and Veterinary Sciences. (12), 31-35.

McMillan, J. \& Woodruff, C. (1999). Interfirm relationships and informal credit in

Vietnam.The Quarterly Journal of Economics. 114(4), 1285-1320.

Megginson, J. (1997). Micro Credit Empowering Farmers in Developing Countries. Ottawa:

Canadian Federation of Agriculture.

Mohammed, A.Q. (2015 b). Employee recruitment, selection and retention in Saudi Arabian

Family owned Small and Medium Scale Enterprises (SMEs) Kuwait Chapter of Arabian

Journal of Business and Management Review. 4(6), February2015.

Murray, J. (2011). Default on a loan, United States Business Law and Taxes Guide National.

Credit Act (2005). Act No. 34 of 2005, Republic of South Africa. Retrieved from:

http://biztaxlaw.about.com/od/glossaryd/g/default.htm.

Obisesan, F.O. Oyedele, O. (2015). Assessment of microfinance institutions as poverty

Reduction. Mechanism in Nigeria. Research Journal of Finance and Accounting. (6), 18-

26.

OECD, (1997). Interim Report on Technology, Productivity and Job Creation - Towards Best

Policy Practice. Submitted to the May 1997 Council at Ministerial Level.

OECD, (2006). Financing SMEs and Entrepreneurs 2006.

Okpugie, G. (2009). High Microfinance Interest Rates Cause Loan Defaults in Nigeria. The Guardian, Nigeria. 
Okwoli, D.M. Abubakar, Y.I. \& Abubakar, I.J. (2013). Microfinance banks and rural Development in Nigeria (2007-2012). International Journal of Capacity Building in Education and Management (IJCBEM).(2), 55-67.

Oladokun, O. (2006). Microfinance to Reduce Poverty Rate. Nigerian Tribune.

Omar, S. S. B. Arokiasamy, L. \& Ismail, M. (2009). The background and challenges faced by

The Small medium enterprises. A human resource development perspective. International Journal of Business and Management. 4(10), 95-102. http://dx.doi.org/10.5539/ijbm.v4n10p95.

Onaolapo, O. (2011). Impact of cooperative financing on MDGS of poverty eradication;

Lesson from Nigeria research. Journal of finance and accounting.

Pack, H., \& Westphal, L. E. (1986). Industrial strategy and technological change: theory versus

Reality. Journal of development economics, 22(1), 87-128.

Park, J. Lim, B. 1 \& Koo, J. (2008). Developing the Capital Market to Widen and Diversify

SMEs Financing: The Korean Experience, Korea Institute of Finance, Seoul.

Qureshi, J. A. (2012). Financial quota of loans for the SME sector in Pakistan: A survey in

Karachi. Interdisciplinary Journal of Contemporary Research in Business. 4(5), 725-741.

Rand, J. (2007). Credit constraints and determinants of the cost of capital in Vietnamese

Manufacturing. Small Business Economics. 29(1/2), 1-13.

Raouf, A. (1998). Development of operations management in Pakistan. International

Journal of Operations \& Production Management. 18(7), 649-650. Http://dx.doi.org/10.1108/01443579810217602.

Sadi, M.A\& Henderson, J.C. (2010). Franchising and small medium-sized enterprises (SMEs)

In industrializing economies: A Saudi Arabian perspective. Journal of Management

Development. 30(4), 402-412.

Shaban, M. Duygun, M. Anwar, M. \& Akbar, B. (2014). Diversification and banks

Willingness to lend to small businesses: Evidence from Islamic and conventional banks in Indonesia. Journal of Economic Behavior \& Organization.

Sheila, A.L. (2011). Lending Methodologies and loan losses and default in a Microfinance

Deposit-Taking institutions in Uganda. A case study of Finca Uganda Kabala Branch (MDI).

Research report presented to Makerere University, Uganda.

Shreiner, M. (2001). A Cost Effect Analysis of the Grameen Bank. Bangladesh Centre for

Social Development, Washington University.

Stanley, G. (2008). Micro Finance is it either a problem or a solution? World Development

Journal(24), 29-41.

Stanley, G. (2008). Micro Finance is it either a problem or a solution? World Development.

Tanaka, K.\& Molnar, M. (2008). What is different about informal finance?

Financing of private Firms in China. Revue Economies. 59(6), 1131-1144.

Thapa, G. (2007). Sustainability and Governance of Microfinance Institutions: Recent

Experiences and Some Lessons for Southeast Asia. Asian Journal of Agriculture and Development.(4), 17-37.

USAID PRISMS, (2005). Nigeria Micro, Small and Medium Enterprises (MSMEs)

Assessment. A Paper Presented at the International Year of Micro Credit (Iymc)

Workshop. 
Warue, B.N. (2012). Factors affecting loan delinquency in Microfinance in Kenya.

International. Journal of Management Sciences and Business Research.(1), 27-48.

Yunus, M. (2008). Creating a World without Poverty; Social Business and the Future of Capitalism. Public Affairs, New York.

Zeitouni, I.Q. (2012). The role of Waqf in Funding Small project. Journal specialized in Waqf \& Charitable Activities, Kuwait Waqf Public Foundation.

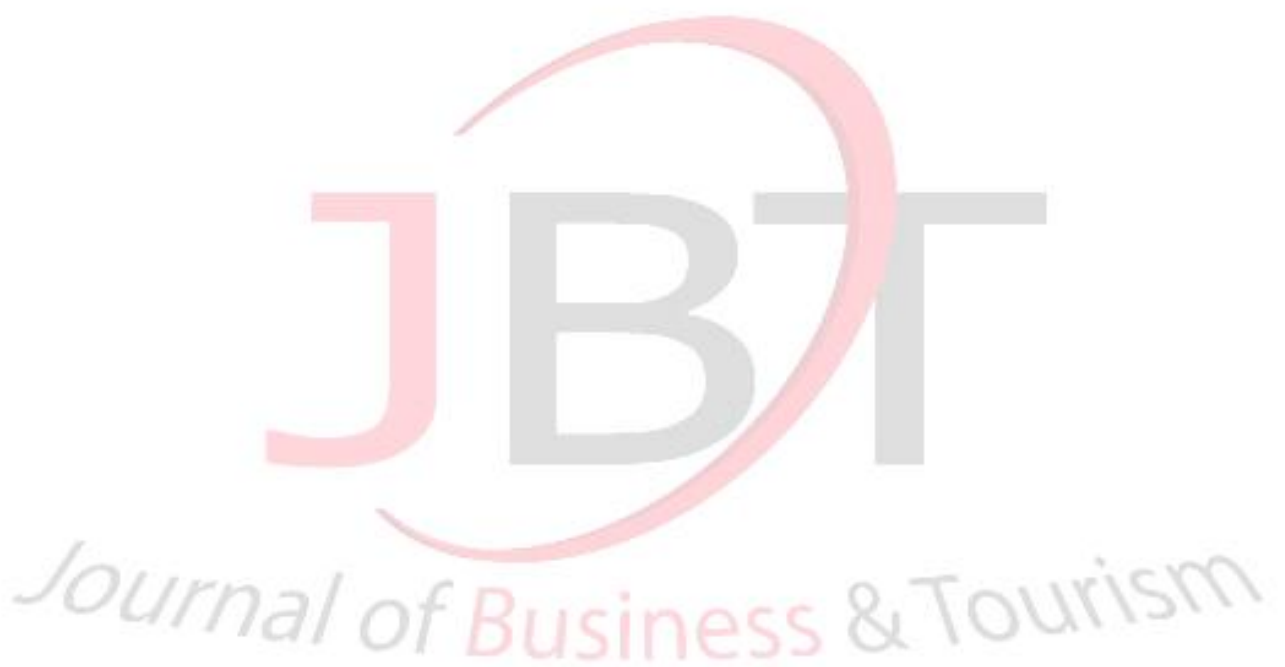

